\title{
Government Intervention and Financial sector development
}

\section{Rashmi Arora}

\begin{abstract}
The contribution of finance to economic growth has been well established in the literature. However, in the recent literature doubts have emerged on the strength and limits of the contribution of financial development to economic growth. Since the financial crisis there has been a renewed interest on the question of the role played by the government in financial sector. Historically, government intervention in the financial sector has prevailed in a number of countries since the decades of fifties until early nineties. Criticisms against financial repression and poor performance of public banks in the form of non-performing loans, low quality of lending, lending to cronies and political allies in several countries, however, turned the tide against government intervention. As a result, the nineties saw the introduction of financial sector reforms in several developing countries with the objectives of improving allocative efficiency of the financial institutions and financial markets. The recent global financial crisis and its deleterious consequences has however, once again stirred up debates on the government's role in the financial sector.
\end{abstract}

The findings however, remain inconclusive although the positive role played by the public sector banks during the financial crisis has been acknowledged in the recent literature. This stance is in stark contrast to the earlier literature on public banks according to which "state ownership tends to stunt financial sector development, thereby contributing to slower growth". Nonetheless, the findings of the emerging literature focus on the positive countercyclical role played by the public banks during crises times and on the government's useful role in supervision and regulation, in building financial infrastructure and in promoting macroeconomic stability. 
The scarcity of capital in Russia was such that no banking system could conceivably succeed in attracting funds. . . Supply of capital for the needs of industrialization required the compulsory machinery of the government (Gerschenkron 1962) pp 19-22).

...whatever its original objectives, state ownership tends to stunt financial sector development, thereby contributing to slower growth (World Bank 2001.p.123)

\section{Introduction}

The contribution of finance to economic growth has been well established in the literature (King \& Levine 1993a, b; Levine 1997). However, in the recent literature doubts have emerged on the strength and limits of the contribution of financial development to economic growth (Arcand, Berkes and Panizza 2015; Law and Singh, 2014; Beck, Degryse and Kneer 2014). The role of government and markets in the financial sector has remained contentious as well and despite a voluminous literature on the subject, questions still persist on what should be the role of government in the financial sector. On the one hand, lending activities of government owned banks is considered counter-cyclical, focus on long-term lending, target sectors/firms/industries neglected or overlooked by the private sector, enhance banking habit and promote financial inclusion. On the other hand, non-performing loans, quality of lending, financial repression, lending to cronies and political allies marred their performance and examples of this exist across both the developing and developed countries. Since the financial crisis there has been a renewed interest on the question of the role played by the government in financial sector. A significant number of studies have emerged in the postcrisis period. However, despite a plethora of studies on the subject the issue still remains controvertible, though a consensus seems to be appearing at least on the countercyclical role of public banks.

Three strands of literature exist on the issue of government intervention in the financial sector. First is the so-called development view according to which the government should intervene and develop financial institutions especially in the early stages of a country's economic development. For instance during the period 1950s and 1960s, a number of developing countries adopted a supply-oriented approach to finance in order to catch up with the developed countries. Other reasons were large size of projects; lumpiness of investments, and scarcity of capital (Gerschenkron, 1962). With the supply-leading approach to the financial institutions pursued in many developing countries, the policymakers perceived that government could step in and jumpstart financial and economic development (La Porta, 
Lopez-De-Silanes, \& Shleifer, 2002). Those against government intervention (also known as political view) have argued that it leads to misallocation of resources, political interference, inefficiencies and lower financial development. There is a third strand of literature which argues that government intervention in the financial sector is fine as long as it is for building financial infrastructure, carrying out institutional and regulatory reforms and improving competition.

This chapter presents evidence from the literature highlighting different views on the role played by the government in financial development. The chapter is organized as follows. Section 2 examines the arguments in favour of government intervention. The next section looks closely at the literature which argues against state intervention in the financial sector. Section 4 synthesizes the arguments and presents a balanced view. Finally, the last section of the chapter concludes.

\section{Government should intervene}

The justification for government intervention in the financial market has rested on the grounds of market failure, safety and soundness of the banking system, to finance socially valuable projects and provide access to financial services to rural areas and less developed regions (Yeyati et al. 2005). In India for instance, the objective of the nationalisation of the major banks which took place in two phases in 1969 and 1980, was to enhance credit to selected sectors such as agriculture, promote balanced regional development and support rural areas. The Narasimham Committee Report on financial sector reforms (Narasimham, 1991) summarised the objectives of nationalisation as:

Nationalisation was recognition of the potential of the banking system to promote broader economic objectives such as growth, better regional balance of economic activity and the diffusion of economic power. It was designed to make the system reach out to the small man and the rural and semi-urban areas and to extend credit coverage to sectors hitherto, neglected by the banking system and through positive affirmative action provide for such expansion of credit to agriculture and small industry in place of what was regarded as a somewhat oligopolistic situation where the system served mainly the urban and industrial sectors and where the grant of credit was seen to be an act of patronage and receiving it an act of privilege (Narasimham, 1991, p.9).

Stiglitz (1989, 1994) argued that financial markets are different from other markets and government intervention is required as market failures are pervasive in the financial sector. The major market failures, according to him, that could justify market intervention are monitoring failure; externalities of monitoring and selection; failure of a financial institution 
and its consequences for the whole economy; missing and incomplete markets; imperfect competition; and difference between private returns and social returns and finally uninformed or less informed investors. Besley (1994) argued that government intervention is justified in the rural credit markets as they face constraints like poor availability of secure collateral (mainly due to poverty and less developed institutions), low institutional development, risks involved in lending to agriculture and segmented credit markets. Stiglitz (1989) further emphasised that since information is not perfect, prices and markets are not perfect and hence there can be market failures in financial markets. Spratt (2009) maintained that government intervention in the financial sector is required for 'production of public goods' where private sector may not be interested as it cannot appropriate externalities; presence of market failures; and redistribution of income.

Panizza (2012) suggested that the choice of market or government or a combination of them will depend on a country's stages of economic development. The state owned banks may play a useful role in supporting and developing financial sector in the early stages of economic development when institutional quality is low and socially profitable investments may not be taken up due to market imperfections (Panizza 2012). Also, the private sector may not have the incentives to establish financial institutions and the other alternative source could be informal financial sector (Yeyati et al. 2007; Micco and Panizza 2006; Detragiache et al. 2005). Further, in the early stages of a country's economic development, arm's length relationship as in market led financial development may not be preferred. Relationship banking in contrast to arm's length relationship is able to overcome informational barriers through regular interactions with the borrowers and through constant monitoring banks are able to provide borrowers credit for long periods especially at the time of crisis (Beck, Degryse, De Haas and Van Horen 2014).

Direct ownership of banks also helps in building trust of people in the banking sector and develops banking habit of the population (Gerschenkron 1962; Andrianova et al. 2008). The rapid spread of bank branches in the developing countries during 1950s and 1960s stemmed from the belief that the development of banking habit (i.e., the practice of going to the banks, and performing banking transactions) may precede, or itself promote, the real growth of the economy (Porter, 1966). Porter (1966) noted that the development of the habit of banking would lead to increased savings and investment, improve the efficiency of allocation of 
capital, and increase the ability of monetary authorities to stabilise the economy. Lewis (1955) also had argued:

Experience shows that the amount of saving depends partly on how widespread these facilities (i.e. savings institutions) are: if they are pushed right under the individual's nose---people save more than if the nearest saving institution is some distance away (Lewis, 1955, p.229).

In the Indian context for instance, a beneficial effect of massive branch banking was the inculcation of banking habits, which spread among the population, rural and urban alike, and led to increased savings. Among the few studies on the impact of bank branches and subnational economic development, Burgess and Pande (2003) examined India's branch expansion policy of 1:4 for commercial banks, which was implemented in 1977 and discontinued in 1990. The rule allowed banks to open a new branch in a location with one or more bank branches, only if they open four branches in locations with no bank branches. Between 1977 and 1990, this rule encouraged banks to open rural branches in states with initial lower financial development. The authors identified the impact of opening a new rural branch on poverty and output, and their results suggested that a 1 per cent increase in the number of rural banked locations reduced rural poverty by 0.36 per cent and increased total output by 0.55 per cent. The rural bank branch expansion also increased non-primary sector output, and non-agricultural employment.

A more recent literature suggests that public banks contribute to and provide lending support during periods of financial instability and economic recessions thus leading to financial stability, avoid extreme moral hazard problems associated with the private sector banks; encourage constrained behaviour often accompanied with the development objectives and promote economic growth (Andrianova et al. 2009; Andrianova 2012; Cole 2009; Bertay, Demergüc-Kunt and Huizinga 2015; Coleman and Feler 2015; Panizza 2012; Yeyati, Micco and Panizza 2007; Micco and Panizza 2006).

Credit by state banks is less procyclical and less responsive to macroeconomic shocks than credit through private banks. For example, during the 2008 financial crisis, state owned banks continued providing funds to the real economy in contrast to withdrawal by private and foreign banks (Coleman and Feler 2015). Micco and Panizza (2006) examined the lending behaviour of public banks during the business cycles. They conjecture that public banks may 
play a positive role in restoring stability due to various reasons such as their development mandate; public trust and considered safer than the private banks; lesser incentive to bank managers to respond aggressively to cyclical fluctuations even during the downturns and finally political factors could influence lending. Their findings show that overall state owned banks play 'credit smoothing' role and contribute to stability. Other studies which have observed low responsiveness of public banks to cyclical fluctuations compared to the private banks are Cull \& Martinez-Peria (2013) and De Haas et al. (2015). Brei and Schclarek (2013) empirically examined the lending pattern of public and private banks and Latin American countries over the period 1994-2009. They examined this in the context of 764 major banks from 50 countries with 63 government owned banks. Similar to the findings of earlier studies, the authors find evidence that government owned banks play countercyclical role during the time of crisis. The authors conjecture that lending by public banks is slower during normal times (that is, a crisis free period), it however, rises during the downturns compared to the reverse lending behavior of private banks which are more cautious and risk averse. ${ }^{1}$ Based on their empirical findings, the authors propose an active role for government in the financial sector especially during the downturns. Some country specific studies also observed positive role of government owned banks during crises period (Coleman and Feler 2015; Foos 2009; Lin et al. 2014; Leony and Romeu 2011).

In another study, Brei and Schclarek (2015) theoretically modelled differential lending responses of public and private banks. In an overlapping intergenerational model the stakeholders- depositors, firms, private and public banks interact together. Their model focused on the portfolio allocation decisions of the banks and considered risks involved in such decisions. They show that the responses of public banks and private banks differ as in contrast to the private banks which reduce lending in crisis times, public banks continue to provide credit to the rest of the economy. Their reasoning for such an occurrence is based on three grounds: development objectives of public banks; promoting stability and recovery of the economy; higher trust of the public banks and thus lower withdrawals and less probability of run on the banks and higher probability of recapitalization of public banks in times of crisis.

\footnotetext{
${ }^{1}$ In their paper, the word 'normal' appears 31 times, yet the authors however have not defined it clearly.
} 
Easy availability of funds and government guarantees may also make public banks less risk averse enabling more credit (Ivashina and Scharfstein 2010; Coleman and Feler 2015). On the role of government guarantees and trust in the financial system, Chabot and Moul (2014) examined the consequences of failed government guarantee in the Indiana state in US in the historical context. They concluded that loss of trust in the regulatory regime had negative long run consequences on the financial depth of the state. Government ownership may be beneficial in the absence of well-developed institutions, high corruption and lack of property rights as it may increase trust of the population in financial system (Panizza 2012). Regulatory constraints and thus low institutional development may lead the government to opt for state owned banks (Panizza 2012).

Again, state intervention in the financial sector may be justified if infrastructure and public goods financing is required. This may also be necessary when large projects exist with lumpiness of investments and if the markets underfund such investments.

\section{Historical evidence on government intervention}

On the reasons for the evolution of financial development and the role played by government and markets, political and historical factors have gained trajectory in the recent literature. Ang (2013) argued that the early role played by the state in promoting the development of the financial sector has not been considered by the existing literature. In his model, Ang (2013) incorporated financial development indicator as the dependent variable (average ratio of private credit to GDP over the period 2000-2009) and state antiquity index and a set of control factors as explanatory variables. For state antiquity index, Ang (2013) employs Putterman's (2004) dataset on the presence of government covering a period of 39 centuries from $1 \mathrm{AD}$ to $1950 \mathrm{AD}$ for 151 countries. The state antiquity index score ranges from 0 to 50 including indicators such as rule by the government instead of tribal rule; foreign or national government; territorial boundaries of the government. The author finds that the countries where governments had intervened and developed institutions (refers to bureaucracy) have higher financial development. He argues that historical accumulation of state experience is important in explaining levels of financial development. 
Andrianova et al. (2011) traced the role of governments in developing major financial centres around the world that is, London, Amsterdam, and Hong Kong. The authors examine the development of these centres in the historical context and highlight the role played by the government in igniting financial development. Other studies which have emphasized positive role of government in financial development in the historical context are Sylla (1999), Rousseau and Sylla (2003) and Sylla, Tilly \& Tortella (1999). These studies showed close association of trading companies with government and its supportive role in financial development. Dehejia and Lleras-Muney (2007) studied the effect of state level banking regulations on financial development and economic growth in US from 1900 to 1940. Their study showed impact of different state level interventions. Thus while bank branching promoted agricultural mechanisation and manufacturing sector development, in contrast state deposit insurance had a negative impact due to inefficient bank lending especially during the economic upturns.

The rapid rise of the East Asian economies since the 1960s also provides a historical evidence on the positive impact of interventionist policies followed by government in the financial sector and in the economy, at large (Wade 1990). Citing the nurturing role played by the financial sector in the East Asian countries leading to their successful economic development, Stiglitz and Uy (1996) cautioned that this was also mingled with market forces, thus both government and market acted complementary to each other. Page (1994) too confirmed,

Much of East Asia's dramatic growth is due to superior accumulation of physical and human capital. But these economies were also better able than most to allocate these resources to highly productive investments. They did this with combinations of policies, always including market-oriented "fundamentals," but sometimes relying on tailored government interventions (Page 1994, p.2).

Vittas and Cho (1994) observed that well-coordinated and focused government interventions in the financial sector was one of the crucial factors in high growth rates achieved by the Asian tigers. Some of the features of the financial sector intervention were close coordination with private sector, close and effective monitoring focused on the achievement of export targets by firms and firms which achieved the targets were rewarded with subsequent credit and similarly credit was reduced for those not able to achieve the targets. Monitoring, for instance was through detailed appraisal of projects and firms' history of repayment of loans. The authors stated, 
Policymakers and economists have long believed that attempts to direct the allocation of credit would not be successful. Yet the experiences of Japan and the Republic of Korea suggest that directed credit programs can increase investment provided countries have a strong institutional capacity for designing projects and appraising and monitoring performance (Vittas and Cho, 1994, p.10).

\section{Role of Development Banks}

More recently since the financial crisis, the role of development banks has come into prominence. De Luna-Martinez and Vicente (2012) defined development bank "as a bank or financial institution with at least 30 percent state-owned equity that has been given an explicit legal mandate to reach socioeconomic goals in a region, sector or particular market segment." The authors surveyed 90 development banks based in 61 countries. ${ }^{2}$ The development banks according to them, provide 'long term credit, loan guarantees, and other financial services in the infrastructure, housing and agriculture sectors'. Their survey showed existence of development banks both in the developed and developing countries providing credit to different sectors such as services, industry, agribusiness, construction and energy. Some of their recent lending in the area of energy has been for activities like clean energy, biotechnology and environmental projects. The survey also noted that development banks are heterogeneous in nature and differ in respect of ownership, policy mandates, deposit taking versus non-deposit taking institutions, targets, lending models, pricing strategies, regulatory regimes and transparency standards. Yet despite these heterogeneities, a common factor among them is their useful role in enhancing financial inclusion. Nonetheless, some of the factors impacting the performance of development banks globally are high subsidies, low or light regulation compared to the banking sector, poor governance and high non-performing loans in some countries.

Development banks in a number of developing countries played countercyclical role during the crisis and provided credit to selective sectors. Gutierrez et al. (2011) highlight the useful and significant role played by development banks during the crisis. The authors suggest that long-term developmental role and the countercyclical role played by development banks should be aligned with each other. They also performed the useful role of increasing access to finance such as to small and medium enterprises. Culpeper (2012) suggests that two major reasons why G20 countries incorporated financial inclusion as a major objective were: to

\footnotetext{
${ }^{2}$ Some of the limitations of their survey are: unconfirmed data; does not explore effectiveness of development banks; distinction between commercial bank and development bank is not very clear in many countries; and finally the survey did not take into multilateral, regional and sub-regional development banks.
} 
reduce the dependence on informal sector; and secondly, to achieve macroeconomic targets of increased investment, employment and economic growth. National development banks can help in achieving these objectives by providing financial services to small and medium enterprises and enhancing financial inclusion.

As the survey by De Luna-Martinez and Vicente (2012) also noted, development banks exist both in the developing countries and developed countries, although not much is known about the developed countries. Rasmussen (2010) in the Norwegian context finds that the government ownership of banks in Norway is well supported with the existence of good institutions and corporate governance standards in the government banks.

Several other authors highlighted the useful role played by the development banks (Hanson, 2004; Rudolph 2009; Schmit 2011). Brazil Development Bank (BNDES) in Brazil has played a very developmental and useful role especially during the crisis (Hochstetler and Montero 2013). It has lent funds to large as well as small enterprises in all the sectors including energy related projects, supported innovation and technological development including support to $\mathrm{R} \& \mathrm{D}$ expenditure including pharmaceutical research. Although a large proportion of the loans were to the 'leader firms' and 'national champions' that is, large established firms, substantial loans were also to the small enterprises, to expand production of new products, small power plants, rural cooperatives and microcredit to small firms (Hochstetler and Montero 2013).

In contrast to the strategy followed by many countries in promoting and establishing development banks and channel them as a countercyclical tool during the crisis, in India several development banks were closed down or merged with their parent institution during the nineties. This policy deprived industrial sector and manufacturing in particular as a useful source of finance (Nayyar 2015; Chandrasekhar 2016; Ray 2015).

Recently in 2014 a multilateral development bank was set up by BRICS (Brazil, Russia, India, China and South Africa) called as New Development Bank as an alternative to IMF and World Bank. The bank was established to promote economic cooperation and mobilise resources for infrastructure and sustainable development projects in BRICS, other emerging economies and developing countries. Another multilateral development bank set up by the developing countries is Asia Infrastructure Investment Bank (AIIB) with the objectives of "development of infrastructure and other productive sectors in Asia, including energy and 
power, transportation and telecommunications, rural infrastructure and agriculture development, water supply and sanitation, environmental protection, urban development and logistics". As these banks have been established very recently, not much is known about their performance.

Some studies have however, challenged the role played by development banks. Among them Lazzarini et al. (2015) conjectured that Brazil Development Bank lends to large profitable firms. The authors further argue that instead of credit to needy firms, the loans are rather granted to established profitable firms. Also BNDES grants credit to the firms which are politically well connected and donate to candidates winning in elections, while those to losing candidates lose out on credit. Similar to the above study, Bonomo, Brito and Martins (2015) examining an unbalanced panel dataset on credit to around 1 million firms in Brazil between the years 2004 and 2012 found that public banks (primarily BNDES) continued providing low cost credit to the firms even after the crisis was over and most of this credit went to large established firms.

\section{Role of government in financial regulation}

Barth, Caprio and Levine (1999) focus on the regulation and supervision of banking sector and examine relationship between regulatory restrictions, government quality and efficiency of banking sector and banking fragility. Using the World Bank database for 45 countries, the authors raise three questions: whether countries with weak government/bureaucratic systems have stricter regulations on banks; whether countries with these stricter regulatory controls have low levels of banking development and finally, whether countries with highly controlled and regulated systems have a lower probability of suffering banking crisis. The authors find that countries with weak governments or bureaucratic systems have stricter regulatory regimes for the banks and the reverse, which shows that countries with better government quality (implying those with lesser bureaucratic controls or red tape, lower corruption level, and strong rule of law) have lesser restrictive regulations especially on real estate and nonfinancial firm ownership. In hindsight, this however, proved to be problematic as Cihak et al. (2012) later showed that banks in 2008 financial crisis affected countries faced lesser restrictions and regulatory controls and were engaged considerably in activities such as real estate lending and other non-financial activities.

Furthermore, Barth et al. (1999) found mixed evidence on the question of whether countries with stricter regulatory regime have low levels of banking efficiency and development. They 
also noted that countries with highly regulatory and stricter regimes face higher probability of crisis. This result especially holds true for the countries where banks are not allowed to diversify their activities such as, securities business. This could be as a diversified banking sector can withstand cyclical fluctuations relatively smoothly. The authors suggest that to improve regulation and avoid banking crisis countries could improve legal systems, increase transparency and information disclosure, set limits on credit to certain sectors such as real estate and diversify loan portfolios. They however, cautioned that adoption of these measures would depend on the country's stage of economic development.

In another study Barth, Caprio and Levine (2004) examining the relationship between regulatory and supervisory practices in 107 countries found that direct government supervision and regulation may not be the best strategy for banking system stability, rather emphasis on information disclosure, privatization of banks with correct incentives will lead to achieving banking development and stability.

\section{Government should not intervene}

Several studies have however, failed to find any evidence of positive impact of government intervention in the financial sector. While evidence against interventionist policies had been building up over the years, the turning point was the publication of Mckinnon (1973) and Shaw (1973), two books published at the same time on financial liberalization. ${ }^{3}$

The literature on 'financial repression', a concept introduced by McKinnon (1973) and Shaw (1973), questioned the distortionary role played by banks in developing countries and argued in favour of financial liberalisation. This included deregulating interest rates and removing other repressive policies. According to McKinnon (1973) and Shaw (1973), loan rate ceilings distort the economy in four ways: i) reduce savings; ii) low yielding projects; iii) lead to capital-intensive projects, and iv) poor quality projects. McKinnon (1973) argued that money holdings and capital accumulation are complementary in the development process. Because of the lumpiness of investment, and reliance on self-financing, savings are needed and high and positive rates of interest play a major part in the mobilisation of savings. Shaw (1973)

\footnotetext{
${ }^{3}$ An exception to this was the positive experience of four Asian tigers (South Korea, Singapore, Taiwan and Hong Kong). Among the various factors responsible for their achieving high growth rates state interventionist policies including those in the financial sector have been noted by various studies.
} 
emphasised the importance of financial liberalisation for financial deepening and the beneficial effect of high interest rates on savings and investment.

During the early seventies, there was an increasing criticism of the interventionist policies of governments. Emphasis was laid on their removal and thus markets, prices and incentives were the focal points (Meier \& Rauch, 2000). Many studies argued that markets, rather than state intervention, would allocate resources efficiently. Cole and Slade (1991) for example, remarked: "The policies deriving from these theories have failed to take account of the complex nature of finance and its multidimensional role in the economy. Instead they have led to distortion and misuse of finance" (Cole \& Slade, 1991, p.316).

In a highly cited study La Porta, Lopez-de-Silanes and Shleifer (2002), arguing against the government ownership of banks, indicated that government ownership of banks leads to misallocation of resources and hurts financial development and economic growth. Among their other findings were that government ownership of banks is pervasive and exists among large number of countries and tends to be high in low-income countries. Andrianova et al. (2009) however, showed that if other variables such as institutional quality and governance quality are included, La Porta's (2002) results do not hold. They concluded, "widely publicised negative effect of government ownership of banks was clearly the result of omitted variable bias, rather than the true effect of government owned banks on the long-run average growth rate."

Among other studies which showed that government ownership hurts are Barth et al. (1999). Caprio and Peria (2002) too argued that government ownership of banks may lead to banking crisis. Dinc (2005) questioned whether government owned banks behave differently during the elections and does their lending increase during the election years. The study provided the evidence that government owned bank lending is politically motivated compared to the private banks. Sapienza (2004) finds that state owned banks charge lower interest rates than private banks. Khwaja and Mian (2005) too in the case of Pakistan found evidence of high politically connected lending by government owned banks particularly if the political party is in power. Cornett, Guo, Khaksari and Tehranian (2010) examined difference in the performance between state owned and private banks in 16 countries in the Far East for the period 1989 to 2004 . They found negative relationship between government ownership and bank performance mainly due to incentive structure of the bank managers and politicians. 
Their results also showed that in the post Asian crisis period 1997 to 2000, deterioration in credit quality of the government owned banks was greater than that of the private banks. More recently, Carvalho (2014) provided evidence on politically motivated lending and employment for Brazil. Iannotta, Nocera and Sironi (2013) examining a sample of 210 large Western European banks during the period 2000 to 2009 also confirmed presence of political factors in influencing lending outcomes. Yeyati, Micco and Panizza (2005) argued that although public banks performed some useful functions such as building trust among the public and performing development functions, the evidence is rather mixed.

Some studies highlighted the negative influence of regulated policies in the banking sector. Demetriades and Luintel (1996) examined the effects of repressive banking sector policies (interest rate controls, reserve and liquidity requirements, directed credit programmes) on financial deepening in the pre-reform period in India. Their results suggested that these policies had a negative influence on financial development. Ketkar and Ketkar (1992) concluded that credit allocation schemes had a negative effect on deposit mobilisation and capital accumulation. They observed this result based on the hypothesis that enhanced and easy access to external credit reduced the need to generate internal finance, thereby depressing financial savings. Meyer and Nagarajan (2000) noted that the evolution of the financial system in India was a consequence of constant governmental intervention over the decades since independence. The study observed that while aggressive branch banking led to the decline in average population per bank branch, the other policies such as directed credit, loan waivers, subsidies and bailing out of non-performing institutions have contributed to a weakening of the banking sector. These studies did not take into account the positive contribution made by the banks in India in terms of creating awareness for the financial products, sources of finance, and outlet for savings (Joshi \& Little, 1996). This is particularly noteworthy in view of the inadequate development of a market-based financial systems in the country, and the only other source of finance being the informal market.

Xiao and Zhao (2011) in their study, using World Bank survey data on 28,000 firms from 46 countries, examined whether markets or banks matter for firms' innovation. The study found that while development of stock markets has a positive effect on the firms' innovation, banking sector development, especially the public banks have a negative effect on firms' innovation. This result is found significantly stronger for the smaller firms. Bertrand et al. (2007) examined effects of banking reforms on industrial structure in France and argued that 
deregulation with the lower effect of bank lending has led to increased competition. Also more efficient allocation of resources takes place as a result of fall in government intervention.

Herring (2010) analysed the role of various policies which actually contributed to the crisis and the role of principal-agent problems in the public as well as the private sector. This also resulted in large number of bailouts organised by the governments funded by taxpayer money. The author suggests that market discipline by the stakeholders is the key to dealing with the crisis. Dell'Ariccia, Detragiache and Rajan (2008) do not find evidence that government interventions such as guarantees and bank recapitalizations can mitigate the effects of the crisis. Claessens, Klingebiel, and Laeven (2005) also indicated that government interventions to reduce the impact of financial crisis on total output have not been effective. A similar such finding is also observed by Klingebiel, Kroszner, and Laeven (2001) who assessed stock market responses to bank restructuring policies and find that public interventions in banks are largely ineffective. Farhi and Tirole (2012) observed that bailouts by the government resulted in increased leverage of private institutions and also high social costs. Giannetti and Simonov (2013) using Japan's recapitalisation of banks during the 1990s crisis as a case study, examined its impact on the performance of firms. Their findings showed that the size of bank recapitalisation matters and small amount of recapitalisations have not been effective in providing bank credit. In contrast, large recapitalisations have benefitted the firms and increased investments.

\section{What is the verdict?}

In between the two stances of intervention and no-intervention is the third middle stance of conditional intervention. This literature argued that government can intervene in the financial sector but only for specific objectives. Cho (2010) argued that the role of state intervention is for prevention, containment and resolution of financial crises. In contrast to the developed countries, the developing countries face twin crises- currency crisis and financial crisis. The study drawing from the experience of South Korea suggests that the important lessons for other countries from Korean experience are: building quality information on financial institutions; political commitment; prompt action and regulatory balance. Beck (2013) outlined the role of government in terms of three sets of policies. These are market development policies (includes policies such as promoting macroeconomic stability, strengthening information framework like credit information bureaus); market enabling 
policies (includes regulatory reforms, reform of tax policies and increasing competition) and finally, is the set of market stabilising policies which includes regulation and supervision, maintaining stability of the financial system, building financial literacy and consumer protection.

Laeven and Valencia (2013) for a sample of 50 developed and developing economies using global financial crisis as a shock to credit supply looked at the impact of government recapitalization of financial institutions on the performance of firms dependent on external finance. The results of the study showed that recapitalization of banks significantly influence growth performance of financially dependent firms through increase in the supply of credit. The authors also found that counter cyclical fiscal policy is more helpful for the firms than monetary policy in dealing with the crisis and its impact on firms once again highlighting positive role of government.

Freixas and Mayer (2011) suggest that the state should play crucial role in five major areas relating to financial sector. These include corporate governance in the private financial institutions (or micro-prudential regulation); macro-prudential regulation covering capital adequacy and liquidity requirements; deposit insurance scheme; promotion of competition and restructuring and recapitalising failing institutions.

Gulde and Wolf (2005) examining the debate on the role of public sector banks cautioned that some factors need to be taken into account when comparing the public sector banks across countries as they could differ by performance levels; extent of influence of government on banks' lending behaviour and type of public banks. There are certain arguments in the favour of public sector banks for instance, preference for social returns over private returns to kickstart development; overcome information problems; develop the trust of public in banking system; to increase access and generate savings from the rural areas thus contributing to financial depth; to smoothen lending by increasing access to credit and finally to promote financial stability. However, there are many arguments against government ownership of banks for instance political capture of banks by the government for its vested interests; public banks may crowd out private financial development; greater likelihood of financial crisis as the quality of public bank loans may be poor. The authors conclude that on balance, the evidence against public banks is mixed and suggest that these banks may be successful provided there is absence of political pressure, good governance standards are 
followed; clear cut performance criteria, focus on clearly specified lending areas and international best practices are followed.

Demirguc-Kunt (2014) suggests that although many other government interventions in the financial sector especially those relating to credit have been controversial and subject to political whims, nonetheless government has an important role to play in building financial infrastructure including protecting creditor rights, regulatory practices and consumer protection. However, the development of such institutions depends on the level of country's economic development. Interestingly, Luo and Wen (2015) contend that institutions are a consequence of economic development and will only develop after a country embarks on the process of industrialization.

\section{Conclusion}

Although a voluminous literature exists on financial sector development and economic growth, the role played by government in financial sector has remained contentious. Historically, government intervention in the financial sector has prevailed in a number of countries since the decades of fifties until early nineties. Criticisms against financial repression and poor performance of public banks in several countries however, turned the tide against government intervention. As a result, the nineties saw the introduction of financial sector reforms in several developing countries with the objectives of improving allocative efficiency of the financial institutions and financial markets. The recent global financial crisis and its deleterious consequences has however, once again stirred up debates on the government's role in the financial sector.

In this chapter we examined, through the lens of the existing literature, whether the government should intervene in the financial sector. The findings however, remain inconclusive although the positive role played by the public sector banks during the financial crisis has been acknowledged in the recent literature. This stance is in stark contrast to the earlier literature on public banks according to which "state ownership tends to stunt financial sector development, thereby contributing to slower growth" (World Bank 2001). Nonetheless, the findings of the emerging literature especially on the positive countercyclical role played by the public banks during crises times and not so positive role in normal times raises contradictory messages for the policymakers. To conclude, despite the mixed opinions on role of government in the financial sector, government's useful role in supervision and 
regulation, building financial infrastructure and promoting macroeconomic stability has been well established. It is also clear from the growth experience of the Asian tigers that governments can lend an effective helping hand to the financial sector and economy and move it in the desired directions especially in the early stages of economic development, provided their objectives are clear accompanied with strong political commitment.

\section{References}

Andrianova, S., Demetriades, P. \& Shortland, A., 2008. "Government ownership of banks, institutions, and financial development, Journal of Development Economics, Elsevier, vol. 85(1-2), pages 218-252, February.

Andrianova, S., P. O. Demetriades, Shortland, A. (2009). Is Government Ownership of Banks Really Harmful to Growth? Economics and Finance Working Paper Series. London, Brunel University.

Andrianova, S., Demetriades, P. and Xu, C., 2011. Political economy origins of financial markets in Europe and Asia. World Development, 39(5), pp.686-699.

Andrianova, S (2012). Public Banks and Financial Stability, Economics Letters 116 (2012), pp. 86-88.

Ang, J. B. (2013). "Are modern financial systems shaped by state antiquity?" Journal of Banking \& Finance 37: 4038-4058.

Arcand, J.L., Berkes, E. and Panizza, U., 2015. Too much finance?. Journal of Economic Growth, 20(2), pp.105-148.

Barth, J. R., G. Caprio Jr., and Levine, R. (1999). Financial regulation and performance: Cross-Country Evidence. World Bank Policy Research Working Paper no. 2037. Santa Monica, Calif.: Milken Institute.

Barth, J.R., Caprio, G. and Levine, R., 2004. Bank regulation and supervision: what works best?. Journal of Financial intermediation, 13(2), pp.205-248.

Beck, T. (2013) 'Finance, growth and fragility: the role of government', Int. J. Banking, Accounting and Finance, Vol. 5, Nos. 1/2, pp.49-77.

Beck, T., Degryse, H and Kneer, C. (2014). "Is more finance better? Disentangling intermediation and size effect of financial system." Journal of Financial Stability 10: 50-64.

Beck, T, Degryse, H, De Haas, R. and van Horen, N. (2014). When arm's length is too far: relationship banking over the business cycle, Working Paper 169, European Bank for Reconstruction and Development.

Bertay, A. C., Demirguc-Kunt, A., Huizinga, H. (2015). Bank Ownership and Credit over the Business Cycle: Is Lending by State Banks Less Procyclical? Journal of Banking and Finance, Vol 50, 326-339. 
Bertrand, M., Schoar, A. and Thesmar, D., 2007. Banking deregulation and industry structure: Evidence from the French banking reforms of 1985. The Journal of Finance, 62(2), pp.597-628.

Besley, T. (1994). "How do market failures justify intervention in rural credit markets?" World Bank Research Observer 9(1): 27-48.

Bonomo, M., Brito, R.D. and Martins, B., 2015. The after crisis government-driven credit expansion in Brazil: A firm level analysis. Journal of International Money and Finance, 55, pp.111-134.

Brei, M. and A. Schclarek (2013). "Public bank lending in times of crisis." Journal of Financial Stability 9: 820-830.

Brei, M. and A. Schclarek (2015). "A theoretical model of bank lending: Does ownership matter in times of crisis?" Journal of Banking \& Finance 50: 298-307.

Burgess, Robin, and Rohini Pande. 2005. "Do Rural Banks Matter? Evidence from the Indian Social Banking Experiment." American Economic Review, 95(3): 780-795.

Caprio, G. and Peria, M.S.M., 2002. Avoiding disaster: policies to reduce the risk of banking crises. Chapter 7 in Eliana Cardoso, Ahmed Galal (eds) Monetary policy and exchange rate regimes: Options for the Middle East, pp.193-230..

Carvalho, D.R. (2014). The real effects of government owned banks: evidence from an emerging market, Journal of Finance, 69, 577-609.

Chabot, B. and C. C. Moul (2014). "Bank Panics, Government Guarantees, and the Long-Run Size of the Financial Sector: Evidence from Free-Banking America." Journal of Money, Credit and Banking 46(5): 961-997.

Chandrasekhar, C. P. (2016). National Development Banks In A Comparative Perspective. Rethinking development strategies after the financial crisis : Volume II: Country Studies and International Comparisons. A. Calcagno, S. Dullien, A. Márquez-Velázquez, N. Maystre and J. Priewe. New York and Geneva, United Nations. II: 21-30.

Claessens, Stijn, Daniela Klingebiel, and Luc Laeven. (2005) "Crisis Resolution, Policies, and Institutions: Empirical Evidence." In Systemic Financial Distress: Containment and Resolution, edited by Patrick Honohan and Luc Laeven, pp. 169-96. Cambridge, UK: Cambridge University Press.

Cho, Y. J. (2010). The Role of State Intervention in the Financial Sector: Crisis Prevention, Containment, and Resolution ADBI Working Paper Series. Tokyo, Japan, Asian Development Bank Institute.

Čihák, M., Demirgüç-Kunt, A., Martínez Pería, M.S. and Mohseni-Cheraghlou, A., 2012. Bank regulation and supervision around the world: a crisis update. World Bank Policy Research Working Paper, (6286). 
Cole, D. and B. Slade (1991). Reform of Financial Systems. Reforming Economic Systems in Developing Countries. D. H. Perkins and M. Roemer, Harvard Institute for International Development: 313-340.

Cole, S. (2009). Financial Development, Bank Ownership, and Growth: Or, Does Quantity Imply Quality? The Review of Economics and Statistics, February 2009, Vol. 91, No. 1, Pages 33-51.

Coleman, N. and L. Feler (2015). Bank Ownership, Lending and Local Economic Performance during the 2008-2010 Financial Crisis. Journal of Monetary Economics, Vol 71, April, 50-66.

Cornett, M.M., Guo, L., Khaksari, S. and Tehranian, H., 2010. The impact of state ownership on performance differences in privately-owned versus state-owned banks: An international comparison. Journal of Financial Intermediation, 19(1), pp.74-94.

Cull, R. and Martinez Peria, M.S. (2013). Bank Ownership and Lending Patterns during the 2008-2009 Financial Crisis: Evidence from Latin America and Eastern Europe. Journal of Banking \& Finance, 37,(12):_4861-4878.

Culpeper, R (2012). Financial Sector Policy and Development in the Wake of the Global Crisis: the role of national development banks, Third World Quarterly, 33:3, 383-403, DOI: $10.1080 / 01436597.2012 .657470$

Dehejia, R. and A. Lleras-Muney (2007). "Financial Development and Pathways of Growth: State Branching and Deposit Insurance Laws in the United States, 1900-1940." Journal of Law and Economics: 239-271.

Dell'Ariccia, G., Detragiache, E., and Rajan, R. (2008) "The Real Effects of Banking Crises." Journal of Financial Intermediation, 17, 89-112.

De Haas, R., Korniyenko, Y., Pivovarsky, A. and Tsankova, T., 2015. Taming the herd? Foreign banks, the Vienna Initiative and crisis transmission. Journal of Financial Intermediation, 24(3), pp.325-355.

De Luna-Martinez, J. and Vicente, C.L., 2012. Global survey of development banks. World Bank Policy Research Working Paper, Vol. 5969.

Demetriades, P. and K. Luintel (1996). "Financial Development, Economic Growth and Banker Sector Controls: Evidence from India." Economic Journal 106(435): 359-374.

Demirguc-Kunt, A. (2014). Presidential Address: Financial Inclusion, Atl Econ J (2014) 42:349-356DOI 10.1007/s11293-014-9429-z

Detragiache, E., Gupta, P., and Tressel, T. (2005). "Finance in Lower-Income Countries: An Empirical Exploration.” Working Paper 05/167. Washington:International Monetary Fund.

Dinc, Serdar (2005). Politicians and Banks: Political Influences on Government-Owned Banks in Emerging Markets. Journal of Financial Economics, 77(2), 453-479. 
Farhi, Emmanuel, and Jean Tirole. (2012) "Collective Moral Hazard, Maturity Mismatch, and Systemic Bailouts.” American Economic Review, 120, 60-93.

Foos, D. (2009). "Lending conditions, macroeconomic fluctuations and the impact of bank ownership." Retrieved April 1, 2016, from https://www.wiwi.uni-

muenster.de/fcm/downloads/forschen/ifk_bankenworkshop/Foos_LendingMacroOwnership_ 200904.pdf.

Freixas, X. and C. Mayer (2011). "Banking, finance, and the role of the state." Oxford Review of Economic Policy 27(3): 397-410.

Gerschenkron, A. (1962). Economic Backwardness in historical perspective- A book of essays. Cambridge, Harvard University Press.

Giannetti, Mariassunta and Andrei Simonov. 2013. "On the Real Effects of Bank Bailouts: Micro Evidence from Japan." American Economic Journal: Macroeconomics, 5(1):135-67.

Gulde, A.-M. and H. Wolf (2005). Publicly Owned Banks In The Development Process. Finanzmarkt- und Währungsprobleme von Schwellen- und Transformationsländern. M. Frenkel and H.-R. Hemmer: 115-130.

Gutierrez, E., Rudolph, H., Homa, T. and Beneit, E.B., 2011. Development banks: role and mechanisms to increase their efficiency. World Bank Policy Research Working Paper Series, Vol. 5729

Hanson, James A. (2004): The Transformation of State-owned Banks. In: Caprio, G., Fiechter, L., Litan, R. and Pormeleano, M. (eds.): The Future of State-Owned Financial Institutions. Washington, DC, Brookings Institutions Press

Herring, R. J. (2010). "How Financial Oversight Failed \& What it May Portend for the Future of Regulation." Atlantic Econmic Journal 38: 265-282.

Hochstetler, K. \& Alfred P. Montero (2013). The Renewed Developmental State: The National Development Bank and the Brazil Model, The Journal of Development Studies, 49:11, 1484-1499, DOI: 10.1080/00220388.2013.807503

Iannotta, G., Nocera, G. and Sironi, A., 2013. The impact of government ownership on bank risk. Journal of Financial Intermediation, 22(2), pp.152-176.

Ivashina, V., and Scharfstein, D. (2010). Bank Lending During the Financial Crisis of 2008. Journal of Financial Economics, 97(3), 319-338.

Joshi, V. and I. Little (1996). India's Economic Reforms, 1991-2001. New Delhi, Oxford University Press.

Ketkar, K. W. and S. L. Ketkar (1992). "Bank Nationalisation, Financial Savings, and Economic Development- a Case Study of India." The Journal of Developing Areas 27(October): 69-84.

Khwaja, Asim, and Atif Mian (2005). Do Lenders Favor Politically Connected Firms? Rent Provision in an Emerging Financial Market. Quarterly Journal of Economics, 120(4), 13711411. 
Klingebiel, D., Kroszner, R. and Laeven, L. (2001) "Stock Market Responses to Bank Restructuring Policies during the East Asian Crisis.” World Bank Policy Research Working Paper No. 2571.

King, R. G. and R. Levine (1993a). "Finance, entrepreneurship and growth." Journal of Monetary Economics 32(3): 513-542.

King, R. G., \& Levine, R. (1993b). Finance and Growth: Schumpeter might be right. Quarterly Journal of Economics, 108(3), 717-738.

Laeven, L. and F. Valencia (2013). "The Real Effects of Financial Sector Interventions during Crises." Journal of Money, Credit and Banking 45(1): 147-177.

La Porta, R., Lopez-de-Silanes, F. and Shleifer, A., 2002. Government ownership of banks. The Journal of Finance, 57(1), pp.265-301.

Law, S. H. and N. Singh (2014). "Does too much finance harm economic growth?" Journal of Banking \& Finance 41: 36-44.

Lazzarini, S. G., Musacchio, A, Bandiera-De-Mello, R., Marcon, R. (2015). What Do StateOwned Development Banks Do? Evidence from Brazil, 2002-2009. World Development, Vol. 66, 237-253.

Leony, L. and Romeu, R. (2011). A model of bank lending in the global financial crisis and the case of Korea. Journal of Asian Economics 22 (4), 322-334.

Levine, R. (1997). "Financial Development and Economic Growth: Views and Agenda." Journal of Economic Literature 35(2): 688-726.

Lewis, W. A. (1955). The Theory of Economic Growth, George Allen and Unwin.

Lin, Y., Srinivasan, A. and Yamada, T., 2015. The effect of government bank lending: Evidence from the financial crisis in Japan. Available at SSRN 2544446.

Luo, J. and Wen, Yi (2015). Institutions do not rule: Reassessing the driving forces of economic development, Working Paper 2015-001A, http://research.stlouisfed.org/wp/2015/2015-

001.pdf Federal Reserve Bank of St. Louis, St. Louis, MO, 63166

McKinnon, R. I. (1973). Money and Capital in Economic Development. Washington D.C., Brookings Institution.

Meier, G. M. and J. E. Rauch (2000). Leading Issues in Economic Development. New York, Oxford University Press.

Meyer, R. L. and G. Nagarajan (2000). Rural Financial Markets in Asia: Policies, Paradigms, and Performance, A Study of Rural Asia, Oxford University Press. 
Micco, A. and U. Panizza (2006). Bank Ownership and Lending Behavior Working paper n. 67 Department of Public Policy and Public Choice - POLIS , UNIVERSITA’ DEL PIEMONTE ORIENTALE “Amedeo Avogadro” ALESSANDRIA.

Narasimham, M. (1991). Report of the Committee on the Financial System. New Delhi, Ministry of Finance, Government of India.

Nayyar, D. (2015). "Birth, Life and Death of Development Finance Institutions in India." Economic \& Political Weekly L(33): 51-60.

Page, J. (1994). "The East Asian Miracle: Building a Basis for Growth." Finance \& Development 31(1): 2-5.

Panizza, Ugo (2012) "Finance and Economic Development," International Development Policy , 3: 141-160.

Porter, R. C. (1966). "The Promotion of the Banking Habit and Economic Development." Journal of Development Studies 2(4): 346-366.

Rasmussen, A. J. A. (2010). State Ownership in Banking - Theory applied to a case study of the Norwegian government's ownership in DnB NOR. Bergen, våren 2010, Norges Handelshøyskole. Masters Thesis Master Degree in Economics and Business Administration.

Ray, P. (2015). Rise and Fall of Industrial Finance in India”, Economic and Political Weekly, Vol 50, Number 5, January 31.

Rousseau, P. L., \& Sylla, R. (2003). Financial systems, economic growth, and globalization. In M. D. Bordo, A. M. Taylor, \& J. G. Williamson (Eds.), Globalization in Historical Perspective (pp. 373-415). Chicago and London: The University of Chicago Press.

Rudolph, H.P. (2009). State Financial Institutions: Mandates, Governance and Beyond. Policy Research Working Paper Series, 5141. The World Bank.

Sapienza, Paola (2004). The Effects of Government Ownership of Bank Lending. Journal of Financial Economics, 72(2), 357-384.

Schmit, M., Gheeraert, L., Denuit, T. and Warny, C., 2011. Public financial institutions in Europe. European Association of Public Banks.

Shaw, E. S. (1973). Financial Deepening in Economic Development. London, Oxford University Press.

Spratt, S (2009) Development Finance, Routledge.

Sylla, R. (1999). Shaping the US financial system, 1690-1913. In R. Sylla, R. Tilly, \& G. Tortella (Eds.), The state, the financial system and economic modernization (pp. 249-270). Cambridge: Cambridge University Press. 
Sylla, R., Tilly, R., \& Tortella, G. (1999). Introduction: Comparative historical perspectives. In R. Sylla, R. Tilly, \& G. Tortella (Eds.), The state, the financial system and economic modernization (pp. 1-19). Cambridge: Cambridge University Press.

Stiglitz, J. (1989). Markets and Development. Cambridge, National Bureau of Economic Research: 1-20.

Stiglitz, J. (1994). The Role of the State in Financial Markets. Annual Conference on Development Economics. M. Bruno and B. Pleskovic. Washington DC, World Bank: 19-52.

Stiglitz, J. E. and M. Uy (1996). "Financial Markets, Public Policy, and the East Asian Miracle." World Bank Research Observer 11(2): 249-276.

Vittas, D. and Y. J. Cho (1994). "The Role of Credit Policies in Japan and Korea." Finance \& Development 31(1): 10-12.

Wade, R. (1990), Governing the Market: Economic Theory and the Role of Government in East Asian Industrialization, Princeton University Press, Princeton, NJ.

World Bank (2001). Finance for growth : policy choices in a volatile world. Washington DC, World Bank.

Xiao, S. and S. Zhao (2012). "Financial Development, Government Ownership of Banks and Firm Innovation." Journal of International Money and Finance 31(4): 880-906.

Yeyati, E., Micco, A. and Panizza, U., 2005, February. State-Owned Banks: Do they Promote or Depress Financial Development and Economic Growth?”. In conference on Public Banks in Latin America: Myths and Reality. Inter-American Development Bank.

Yeyati, E, Micco, A and Panizza U (2007). "A Reappraisal of State-Owned Banks", Economia 7(2), 209-247. 